\section{Pseudomonas pelvic osteomyelitis in a healthy child}

\section{Nour Akhras, Alexander Blackwood \\ University of Michigan-Ann Arbor, USA}

\section{Abstract}

Pediatric pelvic osteomyelitis is a rare entity. The diagnosis is frequently delayed due to difficulty in confirming the diagnosis. To our knowledge, this is the first case report of Pseudomonas pelvic osteomyelitis in a previously healthy adolescent boy. The diagnosis was made radiographically and confirmed by culture. The patient was treated with Levofloxacin and Gentamicin resulting in a complete recovery.

\section{Case Report}

A previously healthy 13-year-old boy presented to an outside institution with two months of pain that started in the posterior of his left leg and slowly progressed until the pain encompassed the entire pelvis. He was an avid athlete but had no history of trauma. He had intermittent fevers with maximum temperature of $102^{\circ} \mathrm{F}$. A white blood cell count at initial presentation was $12.4 \times 10^{9} / \mathrm{L}$ and an MRI demonstrated a partial tendon tear with strain in the left obturator adductor, minimus and magnus with no bone involvement. Radiographs of the pelvis and femur were negative. A diagnosis of a torn tendon was made and treatment with non-steroidal anti-inflammatory medications was initiated. Pain continued to progress eventually involving the entire lower abdomen. Creactive protein and Erythrocyte Sedimentation Rate were elevated at $13.6 \mathrm{mg} / \mathrm{L}$ and $113 \mathrm{~mm} /$ hour one month into treatment. Computerized Tomography (CT) scan of the abdomen and pelvis with oral and intravenous contrast was negative and a tagged white blood cell scan at six weeks was also negative.

Two months after the initial presentation, the patient was hospitalized for continued pain and a 20-lb weight loss. On admission, the patient was afebrile but exhibited significant pelvic discomfort. Exam of the head, neck, chest and abdomen revealed no abnormalities. Musculoskeletal exam showed decreased flexion at the right knee with moderately decreased internal rotation of the right hip. There was severe tenderness with palpation over the right buttock and right ischial spine.
No fluctuance or overlying skin changes. The patient could not bear full weight on his right leg. Bilateral femur and pelvic radiographs showed focal demineralization surrounding the left hip. Focal periostitis was seen on the left ischium and left inferior pubic ramus. Bone scintigraphy showed increased blood flow, blood pool and delayed radiotracer uptake primarily involving the right ischium and posterior aspect of the right inferior pubic ramus. MRI demonstrated extensive signal abnormality and post-contrast enhancement of bilateral ischiopubic and adjacent soft tissue structures with a small peripherally-enhancing fluid collection medial and posterior to the right ischial tuberosity. CT-guided aspirate revealed purulent material and the biopsy was consistent with an acute osteomyelitis. Culture from the aspirate grew Pseudomonas aeruginosa and the patient was treated with Levofloxacin and Gentamicin. Although the patient had improved significantly, there was continued pain at the 6-week follow-up visit so the Levofloxacin was continued to complete a 6 month course. At the 6-months follow-up visit, the patient was asymptomatic and antibiotics were discontinued.

\section{Discussion}

Osteomyelitis of the pelvis is a rare entity in children with an estimated incidence of 1-11\% of all hematgoenous osteomyelitis. ${ }^{1}$ It is difficult to diagnose because of the rarity of infection and difficulty localizing the site of infection. Common misdiagnoses include septic arthritis or synovitis of the hip, appendicitis, cellulitis, pelvic inflammatory disease and nephrolithiasis. There is a general delay in diagnosis with mean duration of illness prior to diagnosis of 11 days. ${ }^{1,2-4}$ Pelvic osteomyelitis occurs more frequently in older children (mean age 8.7 years), affects males slightly more and is less likely to present after antecedent trauma. ${ }^{1,2-6}$ It usually occurs in a single bone with the ilium ${ }^{1-3,5-6}$ being the most affected site.

The most common presenting complaints are fever and pain. Other symptoms include limp or inability to bear weight on affected side. In children non-specific complaints such as anorexia and weight loss can also occur. ${ }^{2}$ The most common clinical findings are tenderness, fever, inability to bear weight, antalgic gait and decreased hip range of motion, although this is less sever than in children with septic arthritis. ${ }^{4}$

Common laboratory findings include an elevated ESR and CRP as well as an elevated white blood cell count, however, the diagnosis should not be excluded based on normal laboratory values. ${ }^{1,3}$ The most frequently recovered organisms are Staphylococcus aureus with up
Correspondence: Alexander Blackwood, $1500 \mathrm{E}$ Medical Center Drive, D5101 Medical Professional Building, Ann Arbor, MI 48109-5718, USA.

Tel. +1.734.763.2440 - Fax: +1.734.232.3859.

E-mail: rab@umich.edu

Key words: osteomyelitis, pelvis, Pseudomonas

Received for publication: 23 June 2011.

Revision received: 11 November 2011.

Accepted for publication: 14 November 2011.

This work is licensed under a Creative Commons Attribution NonCommercial 3.0 License (CC BYNC 3.0).

(C) Copyright N. Akhras and A. Blackwood, 2012 Licensee PAGEPress, Italy

Infectious Disease Reports 2012; 4:e1 doi:10.4081/idr.2012.e1

to $50 \%$ of cultures being negative. ${ }^{2}$ Other organisms infrequently found were $H$. parainfluenzae, Salmonella, Group A Streptococcus, E. cloacae, $P$. aeruginosa, and $K$. kingae.

Bone scans are frequently positive earlier in the course of pelvic osteomyelitis as compared with radiographs, however, a negative bone scan does not exclude the diagnosis. MRI may be the most sensitive and specific diagnostic test with sensitivity reported between $82-100 \%$ and specificity between $75-96 \%$. MRI generally is positive by day $3-5$ of illness. ${ }^{7}$ It is also useful in determining the extent of infection and distinguishing between soft tissue infection and bony involvement. Ultrasound may be a non-invasive initial test that can be used to diagnose pelvic osteomyelitis as long as the clinician suspects the diagnosis. In one small study, the overall sensitivity and specificity of ultrasound was $86 \%$ and $100 \%$ respectively. However, ultrasound is only helpful if the study is specifically directed to look at the deep softtissues of the pelvis. ${ }^{8}$

Surgical drainage and debridement may be necessary depending on extent of disease, response to antibiotic therapy and possible development of an extra-osseous abscess but due to the substantial blood flow to the pelvic bones, antibiotics are generally sufficient in treating pelvic osteomyelitis. Most patients were treated for 4-6 weeks.

The most common complication of pelvic osteomyelitis is abscess formation in adjacent musculature. Other complications that have been reported include fusion of the sacroiliac joint and deep vein thrombosis in a protein-Cdeficient patient. ${ }^{1}$ Persistent infection due to chronic osteomyelitis or chronic recurrent multifocal osteomyelitis generally resolves with long-term antibiotics. Follow up should be long enough to identify complications such as growth abnormalities and chronic recurrent infections. ${ }^{4}$ Long-term prognosis is generally good provided prompt and adequate duration 
of antibiotic therapy. ${ }^{3,6}$

In conclusion, pelvic osteomyelitis is a rare condition in children. However, clinicians should suspect this diagnosis especially in a school-aged child who presents with fever, pain, limp, and/or inability to bear weight (Table 1). $\cdot^{1-9}$ If the diagnosis is suspected, the initial non-invasive test to consider is a bone scan. Once confirmed, a biopsy with culture should be sent to direct antibiotic therapy. Most patients with acute disease improve with no complications after 4-6 weeks of antibiotic therapy. Adequate follow-up is needed to ensure that the patient remains free of longterm sequelae.

\section{References}

1. Davidson D, Letts M, Khoshhal K. Pelvic Osteomyelitis in Children: A Comparison of Decades from 1980-1989 with 19902001. J Pediatr Orthop 2003;23:514-21.

2. Klein J, Leach KA. Pediatric Pelvic Osteomyelitis. Clin Pediatr (Phila) 2007; 46:787-90.

3. Weber-Chrysochoou C, Corti N, Goetschel P, et al. Pelvic osteomyelitis: a diagnostic challenge in children. J Pediatr Surg 2007;42:553-7.

4. Hammond P, Macnicol M. Osteomyelitis of the Pelvis and Proximal Femur: Diagnostic Difficulties. J Pediatr Orthop 2001;10:1139.
5. Mustafa M, Saez-Llorens Z, McCracken G, Nelson J. Acute hematogenous pelvic osteomyelitis in infants and children. Pediatr Infect Dis J 1990;9:416-21.

6. Zvulunov A, Gal N, Segev Z. Acute hematogenous osteomyelitis of the pelvis in childhood: Diagnostic clues and pitfalls. Pediatr Emerg Care 2003;19:29-31.

7. Pineda C, Vargas A, Rodriguez AV. Imaging of Osteomyelitis: current concepts. Infect Dis Clin North Am 2006;20:789-825.

8. Mah ET, LeQuesne GW, Gent RJ, Paterson, DC. Ultrasonic signs of pelvic osteomyelitis in children. Pediatr Radiol 1994; 24:484-7.

9. Kumar J, Ramachandran M, Little D, Zenios M. Pelvic Osteomyelitis in children. J Pediatr Orthop 2010;19:38-41.

Table 1. Summary of published pediatric pelvic osteomyelitis cases series.

\begin{tabular}{|c|c|c|c|c|c|}
\hline Review, $\mathbf{N}$ & Demographics & Presentation & Treatment & Pathogen & Outcomes \\
\hline Kumar, 2010, n=23 & $\begin{array}{l}\text { Male } 65 \% \\
\text { Mean age NA } \\
\text { Range 1m-13y9m }\end{array}$ & $\begin{array}{l}\text { Limp } 100 \% \\
\text { Fever } 65 \%\end{array}$ & $\begin{array}{l}\text { Debridement } 30 \% \\
\text { IV abx } 100 \% \text { mean } 18.7 \mathrm{~d} \\
\text { then } \mathrm{PO} \text { abx for } 1-12 \text { wks }\end{array}$ & $\begin{array}{l}\text { Blood cx: } \\
\text { Negative } 70 \% \\
\text { MSSA 22\% } \\
\text { MRSA 4\% } \\
\text { Salmonella 4\% }\end{array}$ & NA \\
\hline Klein, 2007, n=31 & $\begin{array}{l}\text { Male } 61 \% \\
\text { Mean age 8y11m } \\
\text { Range } 1.5 \mathrm{~m}-17 \mathrm{y} 9 \mathrm{~m}\end{array}$ & $\begin{array}{l}\text { Pain } 90 \% \\
\text { Fever } 71 \% \\
\text { Limp } 29 \% \\
\text { Weight loss/anorexia 3\% }\end{array}$ & $\begin{array}{l}\text { IV abx } 97 \% \text { ( } 4-6 \text { wks) } \\
\text { PO abx 3\% (4 wks) }\end{array}$ & $\begin{array}{l}\text { Blood cx: } \\
\text { Negative 59\% } \\
\text { MSSA 33\% } \\
\text { MRSA 4\% } \\
\text { K. kingae 4\% } \\
\text { Tissue cx: } \\
\text { Negative 59\% } \\
\text { MSSA 27\% } \\
\text { E. cloacae 5\% } \\
\text { P. aeruginosa 5\% } \\
\text { Salmonella 5\% }\end{array}$ & $\begin{array}{l}\text { Complete resolution } 97 \% \\
\text { Avascular necrosis } \\
\text { of femoral head } 3 \%\end{array}$ \\
\hline $\begin{array}{l}\text { Weber-Chrysochoou, } \\
\text { 2007, } n=19\end{array}$ & $\begin{array}{l}\text { Male } 72 \% \\
\text { Mean age } 8.0 \mathrm{y} \\
\text { Range } 9 \mathrm{~m}-15 \mathrm{y} 7 \mathrm{~m}\end{array}$ & $\begin{array}{l}\text { Limp } 100 \% \\
\text { Fever } 84 \% \\
\text { Hx of trauma } 58 \% \\
\text { Local swelling/erythema } 21 \%\end{array}$ & Abx $100 \%$ & $\begin{array}{l}\text { Blood cx: } \\
\text { S. aureus } 41 \% \\
\text { Tissue cx: } \\
\text { S. aureus } 42 \% \\
\text { S. pneumoniae 8\% }\end{array}$ & Complete resolution $100 \%$ \\
\hline Davidson, 2003, n=64 & $\begin{array}{l}\text { Male } 63 \% \\
\text { Mean age } 11 \mathrm{y} 6 \mathrm{~m} \\
\text { Range 1y2m-17y6m }\end{array}$ & $\begin{array}{l}\text { Pain } 95 \% \\
\text { Limp } 48 \% \\
\text { Fever } 47 \% \\
\text { Hx of trauma } 20 \%\end{array}$ & $\begin{array}{l}\text { IV Abx 97\% } \\
\text { (avg } 4 \text { wks) } \\
\text { I/D } 8 \%\end{array}$ & $\begin{array}{l}\text { Source unspecified } \\
\text { Negative } 50 \% \\
\text { S. aureus } 41 \% \\
\text { S. pneumoniae } 3 \% \\
\text { H. parainfluenzae 2\% } \\
\text { Salmonella } 2 \% \\
\text { GAS } 2 \% \\
\text { Polymicrobial 2\% }\end{array}$ & $\begin{array}{l}\text { Complete resolution 97\% } \\
\text { Persistent infection 3\% } \\
\text { Other complications 5\% }\end{array}$ \\
\hline Zvulunov, 2003, n=146 & $\begin{array}{l}\text { Male } 75 \% \\
\text { Mean age } 8.1 \text { y } \\
\text { Range NA }\end{array}$ & Hx of trauma $17 \%$ & $\mathrm{NA}$ & $\begin{array}{l}\text { Blood cx: } \\
\text { S. aureus } 47 \% \\
\text { S. pneumoniae } 2 \% \\
\text { HiB } 1 \% \\
\text { GAS } 1 \% \\
\text { Tissue cx: } \\
\text { S. aureus } 47 \% \\
\text { S. pneumoniae 2\% } \\
\text { HiB } 1 \% \\
\text { GAS } 1 \% \\
\text { Salmonella } 6 \% \\
\text { Gram-negative bacteria } 3 \% \\
\text { M. tuberculosis } 1 \% \\
\text { Micrococci } 1 \%\end{array}$ & $\begin{array}{l}\text { Recurrent osteomyelitis 2\% } \\
\text { Permanent deformity } 1 \%\end{array}$ \\
\hline Hammond, 2001, $n=16$ & $\begin{array}{l}\text { Male } 75 \% \\
\text { Mean age } 7.0 \mathrm{y} \\
\text { Range } 7 \mathrm{~m}-13.0 \mathrm{y}\end{array}$ & $\begin{array}{l}\text { Limp } 100 \% \\
\text { Fever } 88 \% \\
\text { Hx of trauma } 31 \%\end{array}$ & $\begin{array}{l}\text { IV Abx } 94 \% \\
\text { (3-7 wks) } \\
\text { IV Abx+I/D 6\% }\end{array}$ & $\begin{array}{l}\text { Blood cx: } \\
\text { Negative } 18 \% \\
\text { S. aureus } 36 \% \\
\text { GAS } 27 \% \\
\text { S. pneumoniae } 9 \% \\
\text { Fusobacterium } 9 \%\end{array}$ & Complete resolution $100 \%$ \\
\hline Totals, $n=299$ & Males $206(69 \%)$ & $\begin{array}{l}\text { Limp } 112(73 \%) \\
\text { Fever } 81(53 \%) \\
\text { Trauma } 51(21 \%)\end{array}$ & & & Resolution 268 (97\%) \\
\hline
\end{tabular}

Y,years; M, months; Hx, history; IV, intravenous; Abx, antibiotics; wks, weeks; d, days; cx, culture; MRSA, methicillin-resistant Staph aureus; MSSA, methicillin-sensitive Staph aureus; NA, not applicable; Hib, H. influenzae type B; GAS, Group AStreptococcus. 